Article

\title{
Leadership as Interpreneurship: A Disability Nonprofit Atlantic Canadian Profile
}

\author{
Mario Levesque \\ Politics \& International Relations, Mount Allison University, Sackville, E4L 1A7, Canada; E-Mail: malevesque@mta.ca
}

Submitted: 29 September 2019 | Accepted: 5 January 2020 | Published: 5 March 2020

\begin{abstract}
The entrenchment of the neoliberal state and rise of populist leaders has marginalized the role of voluntary organizations in society. This presents significant challenges for nonprofit leaders in economically challenged areas as it erodes their ability to protect and serve vulnerable populations. Attention turns to maintaining hard fought gains at the expense of making progress. Yet doing so requires new skills and leadership styles to manage organizational change where innovation and transformation are key. Based on 42 qualitative interviews with disability nonprofit leaders in Atlantic Canada, our study aims to characterize this transformation. Using Szerb's (2003) key attributes of entrepreneurship that distinguish between entre-, intra-, and interpreneurs, we find disability leaders have become interpreneurs. We find a strong emphasis on networked service delivery underscoring shared goals, risks and responsibilities, and resources. For disability leaders, cultivating relationships and strong communication skills are essential. In the face of populist desires for state retrenchment, we question how long this collective response can hold given ongoing economic challenges.
\end{abstract}

\section{Keywords}

Atlantic Canada; disability nonprofits; interpreneur; leadership

Issue

This article is part of the issue "Leadership, Populism and Power" edited by Cristine de Clercy (Western University, Canada).

(C) 2020 by the author; licensee Cogitatio (Lisbon, Portugal). This article is licensed under a Creative Commons Attribution 4.0 International License (CC BY).

\section{Introduction}

Leadership in the nonprofit sector including the disability sector has gained importance in the past 30 years as governments have increasingly off-loaded their social policy implementation role to civil society actors (Bennett \& Savani, 2011; Rathgeb Smith, 2012). This has coincided with the rise of populism and, combined, have marginalized the nonprofit sector (LaForest, 2012). This presents significant challenges for nonprofits in economically disadvantaged provinces such as those found in Atlantic Canada (Levesque, 2012). The competitive climate and increased role for disability nonprofits calls into question the role and skills required of their leaders. Specifically, how does the skill set that disability leaders possess align with the competitive funding environment that now exists? While the "nothing about us without us" philosophy guides persons with disabilities, there is also the need to examine disability leaders and how they are being trans- formed, if at all, by the changing context within which they operate.

The aim of this article is to examine disability nonprofit executive directors to take stock of their skill sets and leadership styles and argues that existing leadership models insufficiently capture their operating logic. Given the neoliberal turn and the rise of populism, it is argued that disability leaders have become interpreneurs in this turbulent period of shrinking government support, and it is questioned whether this aids or frustrates social citizenship for people with disabilities. The article begins by situating leadership in relation to the Canadian disability nonprofit sector within the populist discourse. In the second part, the focus is narrowed to executive directors of disability nonprofits in Atlantic Canada and the environment within which they operate. The methods that guide this exploratory study are elaborated in the third part with our results presented in the fourth part. The conclusion underscores our findings that disability non- 
profit leaders are wrestling to define and redefine their roles as they become interpreneurs to ensure their organizations' survival.

\section{Populism, Leadership, and the Canadian Disability Nonprofit Sector}

Populism is a nebulous and contested concept. At its heart are three core concepts best captured in the ideational approach which posits the existence and tension between ordinary people and the elites with politics being the expression of the general will. Populist leaders are typically strong and charismatic and position themselves as the voice of the people in their fight against the elites even though they themselves are often part of the political elite. For liberal democracies such as Canada, populism has both positive and negative effects. On the positive side, voice is given to those individuals that feel marginalized in society. Yet, this voice comes at a cost in that it erodes the ability of traditional sectors of society that struggle to protect and recognize fundamental rights (see, for example, LaForest, 2012; Mudde \& Rovira Kaltwasser, 2017). For example, for voluntary sector leaders such as disability nonprofits, significant challenges arise in the maintenance of hard-fought gains at the expense of making progress. These challenges require new skills.

The rise of the right-wing Doug Ford Progressive Conservative Party in Ontario in 2018 is illustrative. As the "voice of the people," Ford has, among other things, changed labour laws, reformed the education system, cut government regulations, while continually criticizing the "corrupt" press (Kheiriddin, 2019; Wherry, 2018). Yet, it was his attacks on "special interests," services for autistic children in particular, that led to a massive backlash and forced his government to retreat, demonstrating the power of the electorate and the limitations of a populist agenda (Alphonso, 2019).

A similar populist strand is seen post-2000 in Atlantic Canadian provinces, an economically challenged region where opposition is often muted (Pied, 2011; Rodner, 2016; Saillant, 2014). Populist governments have emerged in Newfoundland and Labrador (NL) with the Williams administration, in Nova Scotia (NS) with the Dexter administration, and in New Brunswick (NB) with the Graham and Higgs administrations respectively. Populist sentiments are also evident among opposition parties such as with the People's Alliance Party of NB, which calls for the downsizing of government services in the fight for ordinary people including the elimination of services and rights for "special interests" Francophones, which make up 30\% of the provincial population (Fahmy, 2018).

For disability nonprofits, the rise of populist leaders along with the neoliberal state pose significant challenges. Their position has been transformed from one of policy making to service provision by contracting with the state. Yet, even this is being challenged with the move to increased partnerships with businesses which can compromise their core values (LaForest, 2013; Senior, 2011). The legitimacy of represented groups is also undermined with looming uncertainty among individual citizens regarding who is left to fight for specific rights (e.g., disability) forcing us to rethink forms of representation (Levine, 2016). It also tests the capacity of nonprofit leaders as they increasingly adopt business practices and reinvent themselves in attempts to remain relevant (Dekker, 2019; Edwards, Cooke, \& Reid, 1996). Managing in such an environment is challenging for disability leaders-disability nonprofit executive directors. But where to turn?

\section{Theoretical Framework}

\subsection{Leadership and Organizational Change}

Our current understanding of nonprofit leadership is overly determined by the deep leadership literature on the for-profit sector. Here one can trace the evolution of leadership theory to its early pre-1950s beginnings which focused on identifying the personal attributes of leaders in the belief that leadership was an inherent trait (e.g., Stogdill, 1948). Found wanting (Hemphill, 1949), attention turned to identifying leadership styles and patterns with much attention on task oriented versus more participatory leadership styles (Likert, 1961; Stogdill \& Coons, 1957). By the 1970s, it was recognized that situational settings mediated leadership styles thus giving rise to a series of contingency theories (Fielder, 1967; House, 1971). Recent work integrates these theories into a process of sustaining change recognizing that leadership is a function of roles occupied, influence, and context (Bass, 1985; Kotter, 2012; Yukl, 2006). Research has focused on identifying factors that underpin transformational leadership (Popa, 2012), its use (Wright \& Pandey, 2010), and differences when compared to transactional and collaborative styles (Atwood, Mora, \& Kaplan, 2010; Fisher, 2013; also see MacGregor Burns' [1978] pioneering work).

From an organizational change perspective, like the situation disability nonprofits in Atlantic Canada currently find themselves, emphasis is placed on transformational leadership (Jaskyte, 2004; Lutz Allen, Smith, \& da Silva, 2013). Here, we find charismatic and inspirational traits in leaders who are relations oriented. That is, their focus is on human relations both within and outside of their organizations, in hiring the right people, motivating others, and monitoring their performance. Transformational leaders have superior decision making and interpersonal skills while having a high degree of selfconfidence. They are in it for the "long game" (perseverance) and possess strong communication skills (Derue, Nahrgang, Wellman, \& Humphrey, 2011). They also argue for what they think is right rather than what is acceptable or popular (Bass, 1985). This contrasts with transactional and participatory leadership styles which 
are both largely process oriented. Transactional leadership is largely incremental in its focus on marginal improvements, maintaining performance, reducing resistance, and implementing decisions (Scholten, 2010). Participatory leadership emphasizes the input of people in reaching decisions and can be seen as more democratic (Pearce et al., 2003). Autocratic or top-down, directive-oriented leadership is perhaps the least suited for organizational change often leading to conflicts. This controlling style is usually related to less educated and insecure individuals (Derue et al., 2011).

\subsection{Transformational Leadership}

Transformational leadership is often related to entrepreneurs (for a comprehensive overview see Avolio \& Bass, 2001; Riggio \& Bass, 2005). At the heart of entrepreneurial leadership is venture taking (see Table 1). This involves bringing together the necessary resources (e.g., funding, equipment, people) in order to create a new venture or to take over an existing venture only to significantly transform it seeking enhanced performance. In such processes, the risk is assumed by venture takers with the rewards flowing back to them (Brockhaus, 1980; Gartner, 1985; Szerb, 2003). Risk taking has been found to be equal between entrepreneurs and managers (Brockhaus, 1980) although their motivation differs with entrepreneurs focused on money and fame (Gartner, 1985). Entrepreneurial skills are vast and include the ability to generate new ideas and envision possibilities, the ability to recognize and seize opportunities, the recognition of social and market needs, the ability to manage risks, self-confidence, perseverance, and networking (Jain, 2011; Mitchelmore \& Rowley, 2010). To be clear, entrepreneurs are highly creative individuals that operate independently outside of organizations regarding what and how things get done.

Yet highly creative individuals and agents of change also reside within organizations and are termed intraand interpreneurs as shown in Table 1 . Intrapreneurs are entrepreneurs who work within organizations (internal entrepreneurs). Intrapreneurs are able to marshal significant internal company resources in support of their venture that should lead to increased profits for the company. Unlike entrepreneurs, intrapreneurs are teamoriented but still possess a fair amount of independence within the company. The more success they have, the greater their independence (Pinchot, 1985; Szerb, 2003).

Interpreneurs, on the other hand, were initially conceived as individuals who facilitate a period of revitalization of a company or organization. Interpreneurs are intergenerational and often discussed as family descendants who are able to bridge practices of the past with the future in transforming the organization. Their moti-

Table 1. Attributes of entre-, intra-, and interpreneurs.

\begin{tabular}{|c|c|c|c|}
\hline & Classical Entrepreneur & Intrapreneur & Interpreneur \\
\hline Role & $\begin{array}{l}\text { Create new venture; make } \\
\text { business grow }\end{array}$ & $\begin{array}{l}\text { Create new venture within } \\
\text { existing organization }\end{array}$ & $\begin{array}{l}\text { Continuous development; } \\
\text { exploit new opportunities }\end{array}$ \\
\hline Goal & $\begin{array}{l}\text { Own profit maximization; } \\
\text { glory }\end{array}$ & $\begin{array}{l}\text { Profit maximization within } \\
\text { framework of broader } \\
\text { company goals }\end{array}$ & $\begin{array}{l}\text { Profit maximization along } \\
\text { with other network } \\
\text { member goals }\end{array}$ \\
\hline Risk/Responsibility & $\begin{array}{l}\text { Owns all risk and } \\
\text { consequences }\end{array}$ & $\begin{array}{l}\text { Risk lies with company } \\
\text { owner; limited individual } \\
\text { responsibility }\end{array}$ & $\begin{array}{l}\text { Shared risk and } \\
\text { responsibility among } \\
\text { network members }\end{array}$ \\
\hline Control of Resources & $\begin{array}{l}\text { Owns or controls necessary } \\
\text { resources }\end{array}$ & $\begin{array}{l}\text { Company owns resources; } \\
\text { individual has partial } \\
\text { control of them }\end{array}$ & $\begin{array}{l}\text { Partial ownership and } \\
\text { control of necessary } \\
\text { resources }\end{array}$ \\
\hline Connections & $\begin{array}{l}\text { Informal, vague, } \\
\text { authority-based }\end{array}$ & $\begin{array}{l}\text { Formal, authority-based; } \\
\text { significant independence } \\
\text { from other units }\end{array}$ & $\begin{array}{l}\text { Mixed; hierarchical within } \\
\text { business; associative within } \\
\text { network }\end{array}$ \\
\hline Personal Attribute & $\begin{array}{l}\text { Individual person; works } \\
\text { alone }\end{array}$ & $\begin{array}{l}\text { Team person; works in small } \\
\text { group within company }\end{array}$ & $\begin{array}{l}\text { Network person; works in } \\
\text { collaboration with other } \\
\text { network members }\end{array}$ \\
\hline Skills & $\begin{array}{l}\text { Possesses all } \\
\text { entrepreneurial and } \\
\text { business skills }\end{array}$ & $\begin{array}{l}\text { Most entrepreneurial skills; } \\
\text { fights for resources }\end{array}$ & $\begin{array}{l}\text { Specialized skills; some } \\
\text { entrepreneurial and } \\
\text { business skills; strong } \\
\text { emphasis on social and } \\
\text { communication skills, } \\
\text { ability to cooperate with } \\
\text { network members }\end{array}$ \\
\hline
\end{tabular}

Note: Adapted from Szerb (2003). 
vation is growth, leadership, profit, survival, and family values (Poza, 1988). Interpreneurs are networked individuals and, like intrapreneurs who consider the goals of the company within which they work, also consider the goals of their network members. Successes and risks are shared with network members while interpreneurs own or control the resources they bring to the table. What distinguishes interpreneurs is the emphasis on developing and maintaining their network to ensure success thus underscoring the need for superior social and communication skills and the ability to co-operate with other network members (Hoy, 2007; Szerb, 2003).

\subsection{Executive Directors, Management Challenges, and Leadership}

The executive directors of nonprofits are uniquely positioned at the centre of their organization. This poses management challenges as management is multidirectional. For example, executive directors must manage up to their board of directors. This involves the preparation of financial, human resources, and programmatic information for meetings. It also involves long-term strategic planning related to fundraising, growth, and organizational structure, as well as board renewal. Executive directors also need to manage down to their staff and clients largely surrounding the implementation and evaluation of programs and the assignment of related resources. Executive directors also manage out to their external stakeholders. Managing contracts with government agencies, reporting on financial and program outcomes, and continually cultivating relationships with existing and potential donors is time consuming yet crucial for the organization. Executive directors also need to respond to community group or media inquiries as they arise. Lastly, executive directors manage out to other nonprofits in terms of working collaboratively on programs or advocacy strategies in order to make progress on disability issues. Time is a precious resource and an executive director's attention can be focused on one or more directions depending on priorities or time of year (for a broader overview, see Levesque, in press-a; Mintzberg, 2002).

Two implications arise from this management situation. First, the multidirectional management required is very different from that found in the corporate world. For example, for-profit managers, that is, chief executive officers, typically operate at the halfway point between their board of directors and their staff similar to the pinch point in an hourglass. Management is up or down with very little management out in other directions (a similar situation is found with local government chief administrative officers; see Siegel, 2010).

Second, multidirectional management places a premium on key competencies. The skills required to manage up to boards are not necessarily the same as those required to engage with the media or external stakeholders or to work with clients and staff (Wang \& Ashcraft,
2012). No one executive director possesses all of the necessary skill sets which underscores the need for support from other key individuals with complementary skill sets. This is important given the unpredictability of populist leaders' agendas.

To survive in this environment, change is required. Disability leaders have to be creative and innovative in order to ensure programs meet their clients' needs. The creativity comes from having to reinvent themselves and their organization to remain relevant and to compete for government contracts for service delivery. Innovation means doing things differently including working with other like-minded groups. It is this creativity and innovation that are at the core of transformative and entrepreneurial leadership and enable forward movement. The question is: Do we see evidence of this leadership emerging in Atlantic Canadian disability nonprofits?

\section{Methodology}

This article is derived from the Fostering the Next Wave of Disability Leaders project. This 2.5 year project was aimed at understanding leadership in the disability nonprofit sector in an era of increasing populist leaders to improve disability policy development and program implementation in the post-2000 neoliberal era.

\subsection{Research Context}

Consisting of three parts, part 1 developed a management profile of disability leaders-executive directors of nonprofit disability organizations and government disability program managers. This included distilling the skill sets and tasks performed in order to reveal gaps and to assess how those gaps could be addressed and distinguished. Executive directors were found struggling to keep their organizations afloat due to the loss of core operational funding in the move to competitive contracting. In comparison, government disability officials deviated little from the hierarchical model of management and stressed the need to "manage" superiors and engage project partners. The result is the current patchwork of disability services with individuals increasingly turning to rights-based approaches for policy changes to force governments into cross-departmental personcentred approaches to meet needs, something for which they are poorly structured to do (Levesque, in press-a).

Part 2 of the project is the current work. Given the changes forced upon disability leaders in the post2000 neo-liberal era, how can we characterize what they do? While many are struggling, disability leaders are, nonetheless, surviving. Yet, we are witnessing a transformation from their former managerial role into a "jack of all trades" role with significant innovative and creative entrepreneurial spirit. The characterization of this spirit is the focus here.

Part 3 examined the relationship between disability nonprofit executive directors and their boards of direc- 
tors. It found that the benefits board of directors offer (advice, guidance) were negated by the efforts executive directors spent recruiting and continually educating them on issues to ensure they remained on task. In other words, boards were less than transformative and acted as a brake on executive directors' ability to realize service mandates and lead the organization in challenging times (Levesque, in press-b).

\subsection{Geographical Context}

A qualitative study was conducted containing semistructured interviews with executive directors of disability nonprofits in Atlantic Canada. An Atlantic Canadian disability focus is warranted for several reasons. First, it is an understudied area in the literature yet provides an excellent research laboratory. It is comprised of four small Canadian provinces-NB, NS, Prince Edward Island (PEI), and $\mathrm{NL}-$ each of which have unique yet intertwined histories and similar governance structures. Second, the four provinces are traditionally "have not" provinces and have been economically marginalized from the rest of Canada receiving federal equalization payments (Graefe \& Levesque, 2006). Third, the region is highly rural (48-56\%) with a small population (approximately 2.4 million people combined; Statistics Canada, 2016). Fourth, Atlantic Canada has the highest rate of disability in Canada at $16.3 \%$ (Statistics Canada, 2014) and is served by over 250 disability nonprofit groups (Levesque, in press-a). Lastly, and more broadly, leadership research centred on nonprofit disability organizations is scarce (but see Schalock \& Verdugo, 2012). Combined, these factors offer an excellent opportunity to study leadership transformation, especially with the rise of populist leaders post-2000, the entrenchment of new public management and recent funding cuts to disability organizations. In such situations, disability leaders face greater pressure in fulfilling mandates and we should see evidence of a move to transformative and entrepreneurial leadership.

\subsection{Methods for Data Collection and Analysis}

A total of 42 semi-structured interviews were conducted either in person or via telephone during 2016 and 2017 (see Table 2) with executive directors of disability organizations. Lists of provincial disability organizations were developed via Google web searches and disability group websites. Interviewees selected included a balance of groups from each province representing various disabilities including physical (12 interviews), visual (3 interviews), hearing (5 interviews), mental health (4 interviews), intellectual (5 interviews), and learning ( 0 interviews) disabilities, or a combination thereof (13 interviews). Lastly, disability organizations interviewed differed by whether they were primarily service (32), advocacy oriented (5), or both (5), and varied in scope from local to provincial and national. Participants are referenced as Respondent 1 (R1) and Respondent 2 (R2) to ensure confidentially and anonymity.

Questions probed their leadership approach, tasks performed, skills required, and board of directors relations. Interviews lasted on average 50 minutes and were recorded and transcribed. Each interview transcription was then reviewed three times by the research team to identify key attributes associated with entre-, intra-, and interpreneurs as outlined in Table 1 (role, goals, risk/responsibility, control of resources, connections, personal attributes, and skills). Key passages illustrative of each feature were highlighted with each reading. Analysis and interpretation of these passages was then undertaken to ensure consistency with the entre-, intra-, or interpreneurship categories.

\subsection{Limitations}

One potential limitation is related to the identification and interpretation of key "preneurial" features from the interview transcriptions. While errors may arise when one individual conducts the review, the team approach minimized such errors. Three members of the team reviewed the transcriptions independently then compared analyses to arrive at final results.

A second limitation is the mix of disability organizations with individuals from physical disability and crossdisability nonprofit organizations forming the majority of the interviews. The fact that no interviews were conducted with officials from learning disability organizations even with efforts to reach out to those identified (e.g., contacting all of them twice) was problematic. We were limited to those individuals who voluntarily agreed to participate. The results are dependent on the mix of disability nonprofits responding. However, we are confident in the results given the quality of feedback received from research dissemination events in the four provinces and a cross-provincial webinar with over 60 disability organizations.

Third, caution is required in generalizing the results given only one sector, disability nonprofits, and one economically challenged region, Atlantic Canada, formed the basis of this study. Differences may exist with other types of nonprofits such as those addressing poverty, homelessness, or economic development given sectoral dynamics. Results may also vary in regions with stronger economies in Canada (Ontario or Alberta) or in other

Table 2. Number of interviews conducted (requested), by province and type.

\begin{tabular}{lcccccc}
\hline & & NL & PEI & NS & NB & Total \\
\hline Disability Organizations & \# conducted & 8 & 14 & 9 & 11 & 42 \\
& (\# requested) & $(25)$ & $(25)$ & $(25)$ & $(25)$ & $(100)$ \\
\hline
\end{tabular}


countries given differences in institutional, social, and political structures.

Lastly, while Atlantic Canadian politics post-2000 is tinged with populist leaders such as Darrell Dexter (New Democratic Party) in NS, Danny Williams (Progressive Conservative Party) in NL, Shawn Graham (Liberal Party), Blaine Higgs (Progressive Conservative Party), and Kris Austin (People's Alliance of NB) in NB, we admit that results may differ in regions with a deeper history of populist leaders and politics.

\section{Results}

A move to interpreneurial leadership is evident. We discuss this result in relation to how Szerb's (2003) key features of "preneurs" overlap, then relate it to populist leaders.

\subsection{Disability Nonprofit Executive Directors-Interpreneurs}

\subsubsection{Roles}

Our interviews revealed a move to interpreneurial and transformational leadership with one key distinction: there is no familial dynamic involved. With interpreneurial leadership, the leader is typically a family member who has worked within the organization and moved to lead it into the future by bridging its past while seizing new opportunities in order to remain relevant in the marketplace. Such individuals are a rare entity in the disability nonprofit sector given their small size with most having less than ten employees (many have less than five). The typical situation was for a new executive director to assume the position after working in a similar position elsewhere, then taking stock of the organization to transform it in light of community and market realities.

Executive directors recognize the need for change stating that:

To move the organization forward, like I believe that change has to happen on a daily basis. I really feel strongly that because we are dealing with people's lives and everything changes on a daily basis so as an executive director of an organization, it has to be a visionary. It has to know what the future can look like and what it should be and that type of thing. It doesn't mean that you are totally on the ball but you have to have a vision to then discuss with your board. (R33)

This quote underscores the need to have a vision and a plan but for others, it is more about holistic and continuous change as this quote from an executive director outlines:

So the whole idea is about constantly improving, continuous learning, making yourself better, and applying that knowledge to your job and that makes us bet- ter as an organization. So, it is an interconnectedness thing and a flow, but the whole thing is about learning, constant desire to learn and improve because.... believe that if you stop growing and learning and applying and trying to, you know, organize change or drive change, change is going to drive you and that usually means someone will drive you out the door too, because change is constant. People have to understand that, people don't like change, but change is constant and change is good. (R8)

In the above quote, the executive director is espousing some of the tenets of new public management (Reiter \& Klenk, 2019) in continuous improvement and learning which is consistent with interpreneurialism. R8 also emphasizes adaptability and to making change the norm. In R8's words, "change is constant." This, however, questions how change is to be approached and managed. Again, to quote the same executive director:

I think you manage change by, I think realizing, look for trends in the sector, you realize that change is constant, so it is best for you to make change happen, as opposed to letting change make things happen to you, you know what I mean? So, you try to look at your organization and take note of where you are, what is going on around you, how does that affect us and if it does how do you deal with it effectively. (R8)

\subsubsection{Goals, Risks/Responsibilities, and Control} of Resources

Interviewees emphasized being aware of the "market" and the organization's fit within it, underscoring the need to stop to think, reflect, and plan (R17). This involves conducting asset mapping and environmental scans and creating opportunities to create relationships that may or may not have previously existed with organizations (R13). It is also about being evidenced-based and data driven (R16) which takes time and demands research to make a business case as one executive director pointed out:

We have been trying to develop our own social enterprise or what kind of model that could be, we have identified a market and we are still kind of in that assessment mode of how we can figure out what the size of the market is and what really the demands are. (R4)

Being opportunistic is beneficial as examples from two executive directors point out:

So we had been scrambling to try to find an alternate source of funding because we see just how important that program was and how there is nothing else like it in this province, there is a gap....We worked with government, they were looking to do something to work with...to kind of put a toe in the water for the flex fund- 
ing stuff and it broadened into doing some significant person-centered planning. (R6)

We did a proposal for four schools and United Way gave us enough for two so I met with the school board and said if you want another two it will cost you $\$ 5,000$, which is significantly less than the first two, so we will see if they are open to the idea. (R9)

The above examples highlight two key behaviours. First, there is a search to fit programs in line with government needs. Second, executive directors are searching out new opportunities consistent with interpreneurial leadership yet interpreting the organization's capabilities in government terms with a keen eye to budgets. Note the emphasis on the cost differential in the second quote. At other times, opportunities may be unexpected due to societal change as this next quote reveals:

I think with mental health, everyone can relate to it so therefore it is becoming more important to everybody and we are just finding, like, the third-party fundraisers are increasing like you wouldn't believe, whereas years ago there was no such thing as a third-party fundraiser. If you want to raise money you had to do it yourself. (R9)

The evidence suggests that executive directors are largely interpreneurially oriented. Their focus is on continuous development, launching new ventures while exploiting new opportunities. They are also interpreting situations in government terms more so, which demonstrates consideration of their partners' goals while acknowledging their limitations (funding) which is consistent with interpreneurial leadership (see Table 1).

\subsubsection{Control of Resources and Personal Attributes}

Our interviews revealed a strong networking and collaboration component among executive directors. They cultivate their networks and approach services delivery often as networked-based, sharing expertise and resources (R5, R22), which is consistent with interpreneurial leadership. Networking and collaboration consumed the vast majority of executive directors' time, upwards of $70 \%$ for some (R29, R31). As one executive director explained:

One of the best [pieces of] advice I got from a mentor that worked in the community was [to] get out there in the community; get on committees that are not related to what you do but let people know who you are and what you do; so, extend your reach and let them know you are there, you have got something to offer and you learn things and you make connections. (R8)

This need to continuously cultivate relationships was highlighted, with one executive director stating:
The majority of my job is relationship building $60 \%+\ldots$ because, you know, even in terms of relationships with government funders, you know asking for money is just one small part of it. The rest of it is making sure you are at the public consultations that they expect you to be at and being a part of partnerships. So, you are constantly kind of talking to people within that department to show that you a good partner in terms of somebody that they would want to work with in order to move forward the priorities of the government....So, I think that that part is really important and the ability to juggle a lot of different relationships is really critical because there [are] so many individuals who we touch in our work right, different stakeholders and the people we partner with and the people who give us money. That is the hardest part of this job and you have to be able to manage those partnerships and relationships well. (R34)

The Atlantic provinces have formal networks of disability associations (NL Network of Disability Leaders, NB Disability Executive's Network) or provincial accessibility committees (PEI, NS). The executive directors of those networks found the cross-sector disability approach beneficial to raise awareness, to combine efforts on common issues (e.g., transportation, stigma, discrimination, social supports; R4, R5), and for meeting key decision makers (R39). This does not mean that there is consistent agreement on how to move forward; rather, agreement exists for ongoing discussions and seizing opportunities for change (R33).

While beneficial, formal networks experience problems. Lacklustre attendance hampers information sharing and decision making (R4). Moreover, issues surrounded network membership given membership is by invitation only. As one individual stated:

When you have one group speaking for all disabilities then some disabilities get left to the back because no, I am not a strong believer in cross-disability. You can't be an expert in all disabilities. You can be an expert in some things but not all and I stick to what I know and let the others speak for themselves and often times when you have cross-disability I am often at the table going, oh actually, that is not actually right for my group. (R36)

\subsubsection{Skills, Personal Attributes, and Control of Resources}

Another issue was that funding was disproportionately directed to disability nonprofits that were part of the network, which was lamented by one executive director whose organization was unable to join the network (R5). Still, others noted that it was the wave of the future because "governments are more interested in speaking with multi-disability groups then single-issue disability groups, especially at the federal level" (R38). 
Questions also surrounded what collaboration actually means, especially for smaller disability nonprofits. In the words of one executive director:

One of the things that I find that I am running up against is what does collaborative work actually mean when a large institution is working with a communitybased organization and my experience in...was very different than here and whether it is a lack of knowledge or fear or lack of political will, I am not sure, but the ability to begin to look at what collaborative working from my perspective, from an NGO perspective, seems to be lacking from our government and our large institutions. (R13)

Other executive directors expressed frustration with other organizations arguing that collaboration may be expressed yet actions are often less than collaborative (R21). Frustrations also surrounded dysfunctional networked efforts with some executive directors occasionally asking to be removed from provincial committees (R19).

What we find is a situation where executive directors have all expressed the need for collaboration and networking in order to achieve goals. Yet, this collaboration at times involved only select disability nonprofits to the chagrin of others. The evidence also suggests that collaboration, while plentiful, is imperfect, and much trial and error is involved. One executive director may have said it best by stating:

What is the value of that collaboration? So, being able to communicate, those communication skills and being able to build those relationships and articulate those values without wanting to poke someone's eyes....but the art of patience and understanding that building relationships takes time, whether it is with larger organizations or with clientele. It is not a fast process, it takes a lot of time, it doesn't happen. We don't "friend" somebody you know and that creates a relationship. It is a long process and building trust with whatever organization of group of people you are working with is a slow process. (R13)

\subsubsection{Skills}

At the heart of this shift to "preneurship" is the need for superior communication skills. This includes:

Strong writing and oral skills; you are constantly writing. You are writing press releases, you are writing letters to sponsors, you are writing letters to participants, you are writing letters to parents, you are writing letters to schools, so that is definitely something. (R26)

The above quote illustrates the need to "know your audience" given a different writing style is required for each audience. Knowing your audience means being "peoplecentric" as one executive director explained:

Number one, I think you need to be a people person because you need to be able to connect with people, otherwise they are not going to see you as being available to them for whatever it is they need you for or want you for. (R37)

This again underscores the ability to build and sustain relationships and partnerships (R9) with some executive directors stating that fostering relationships with project funders is over half of their work (R4). The key in this process is:

The ability to be able to write and just craft a story because even if you don't know the contract piece if you can craft a story than you can write the proposal, you know? A level of, I don't even know how to phrase this, but just a level of awareness of the political circumstances of this province and knowing who the players are. The ability to speak well on whatever it is that are speaking and to be aware of how it is that you are presenting things. (R6)

That is big, that storytelling piece, whether it is faceto-face or whether it is in a group, is a big piece of what I do as well and I think it is about trying to make it and communicate it in a way that is succinct, it grabs people's attention, but yet I know it stays focused enough that I know they can walk away with a seed that has been planted, that is big piece of what we do for sure. (R3)

The point is that superior communication skills and relationship building are inter-related and underpin collaboration and partnerships which is consistent with the move to interpreneurship focused on managing networks in order to achieve your goals.

\subsubsection{Control of Resources}

Much of the change has been forced on disability nonprofits due to changes in their funding structure and, in particular, funding cuts. These cuts have occurred due to changes in federal funding formulas and provincial economic realities. Federally, the Harper Conservatives cut core operational funding to disability groups in 2012 which had a knock-down effect. As one official stated:

About three to four years ago, the national office and a couple of the other ones found out they weren't going to receive their traditional funding and they were given a period of, I think it was three years, where the first year they received their normal funding, the next year it was cut by $50 \%$, and the year after that it was cut down to $25 \%$ so basically they were cutting them out. (R5) 
At the same time, federal program funding changes redirected funding to provinces which, in turn, redirected the funds based on their own priorities thus recalibrating funding among disability organizations. Winners and losers were created and, for some, significant funding was lost, upwards of a million dollars (R46). While governments may be sympathetic to disability issues, executive directors realize that there is little money for them (R6). Changes in funding have forced disability nonprofits to innovate. For example, a formerly top-down funding structure with the national organization distributing funds to provincial chapters was reversed so that the provincial chapters now fund the federal office (R15). Disability organizations have also been forced to be more creative in their fundraising efforts given formerly funded national groups are more aggressive at the local and provincial levels which has crowded out funding for many smaller nonprofits. This has forced them to be more creative with fundraising, especially given increased competition from new electronic sites such as Go Fund Me that has multiplied the number of causes competing for the public dollar (R3, R7, R13, R21, R33). A changing funding climate has forced disability nonprofits to innovate to survive. This is consistent with interpreneurship given their desire to transform organizations in order to keep pace with market shifts.

\section{Conclusions}

This article focuses on how the entrenchment of the neoliberal state and the rise of populist leaders in Atlantic Canada has impacted disability nonprofit leaders. Our results indicate that disability nonprofit leaders have become interpreneurs. Their role is to take stock of organizational strengths in order to capitalize on new opportunities while working to redefine how they operate given the new climate. While their focus remains largely on sustaining operations, they are increasingly doing so as part of networks illustrating the fact that risks and responsibilities and the control of resources are now shared. The success of network members is, therefore, of great importance and underscores the value of networking, relationship building, and communication skills. Our results also show how the key interpreneurial leadership features, particularly goals, risks, and responsibilities and control of resources, as well as personal attributes, skills, and control of resources are intertwined.

The implications are significant. In the face of populist desires for state retrenchment, we see the disability nonprofit sector in Atlantic Canada recoiling with increasing dependence on sector networks to survive. Shortterm, this may be an effective survival mechanism. Longterm, attrition of the sector is suggested and increased societal inequality due to elevated services demands and chronic underfunding. As "policy takers," disability nonprofits are vulnerable to populism and question remains as to the severity of the attrition and whether Atlantic Canada is on the same "do-democracy" path as the Netherlands (Dekker, 2019). On the ground, the degree of attrition may be a function of the willingness of disability nonprofits to collaborate. The fact that executive directors have become interpreneurial bodes well for the future.

Looking forward, research is needed on different types of nonprofit organizations and in different economic and political conditions, including the context of populist leaders. There is also a need to examine the types of service delivery collaborations among disability nonprofits and their impacts on people with disabilities. This can then be linked back to state restructuring initiatives under populist leaders to improve the resiliency of disability nonprofits. The framework used here offers a model for gauging this transformation.

\section{Acknowledgments}

The author thanks the Social Sciences and Humanities Research Council (SSHRC) for their generous support of this research through an Insight Development Grant (430-2016-00644), and Marilyn Cox, Caitlin Gallant, Noah Fry, and Anna Paradis for their research assistance.

\section{Conflict of Interests}

The author declares no conflict of interests.

\section{References}

Alphonso, C. (2019, July 29). Ontario government to reverse direction on autism program and provide families with needs-based support. Globe and Mail. Retrieved from https://www.theglobeandmail.com/ canada/article-ontario-government-to-reversedirection-on-autism-program-and-provide

Atwood, M., Mora, J., \& Kaplan, A. (2010). Learning to lead: Evaluating leadership and organizational learning. Leadership \& Organizational Development Journal, 31(7), 576-595.

Avolio, B. J., \& Bass, B. M. (2001). Developing potential across a full range of leaderships: Cases on transactional and transformational leadership. New York, NY: Psychology Press.

Bass, B. M. (1985). Leadership and performance beyond expectations. New York, NY: Free Press.

Bennett, R., \& Savani, S. (2011). Surviving mission drift. Nonprofit Management \& Leadership, 22(1), 217-231.

Brockhaus, R. H. (1980). Risk taking propensity of entrepreneurs. The Academy of Management Journal, 23(3), 509-520.

Dekker, P. (2019). From pillarized active membership to populist active citizenship: The Dutch do democracy. Voluntas, 30(1), 74-85.

Derue, D. S., Nahrgang, J. D., Wellman, N., \& Humphrey, S. E. (2011). Trait and behavioral theories of leadership: An integration and meta-analytic test of their 
relative validity. Personnel Psychology, 64(1), 7-52.

Edwards, R., Cooke, P., \& Reid, N. (1996). Social work management in an era of diminishing federal responsibility. Social Work, 41(5), 468-479.

Fahmy, G. (2018, September 27). Kris Austin defends himself, as Acadian voices against People's Alliance multiply. CBC News. Retrieved from https:// www.cbc.ca/news/canada/new-brunswick/peoples-alliance-and-francophone-groups-1.4840449

Fielder, F. E. (1967). A theory of leadership effectiveness. New York, NY: McGraw-Hill.

Fisher, L. (2013). Transformational leadership among grassroots social service organization. Community Development, 44(3), 292-304.

Gartner, W. B. (1985). A conceptual framework for describing the phenomenon of new venture creation. The Academy of Management Review, 10(4), 696-706.

Graefe, P., \& Levesque, M. (2006). La nouvelle gouvernance fédérale et les politiques sociales au Canada: Leçons des ententes en matière de l'intégration en emploi des personnes ayant des handicaps [The new federal governance and social policy in Canada: Lessons from labour market agreements for persons with disabilities]. Lien Social et Politiques, 2006(56), 73-86.

Hemphill, J. (1949). Situational factors in leadership. Columbus, $\mathrm{OH}$ : Ohio State University.

House, R. J. (1971). A path goal theory of leader effectiveness. Administrative Science Quarterly, 16(3), 321-338.

Hoy, F. (2007). Nurturing the interpreneur. Electric Journal of Family Business Studies, 1(1), 4-18.

Jain, R. K. (2011). Entrepreneurial competencies: A metaanalysis and comprehensive conceptualization for future research. Vision, 15(2), 127-152.

Jaskyte, K. (2004). Transformational leadership, organizational culture, and innovativeness in nonprofit organizations. Nonprofit Management \& Leadership, 15(2), 153-168.

Kheiriddin, T. (2019, June 7). Commentary: Doug Ford's desire to settle scores overshadows his populism. Global News. Retrieved from https://globalnews.ca/ news/5361716/doug-ford-first-year-in-office

Kotter, J. (2012). Leading change. New York, NY: Harvard Business Review Press.

LaForest, R. (2012). Rerouting political representation: Is Canada's social infrastructure in crisis? British Journal of Canadian Studies, 25(2), 182-197.

LaForest, R. (2013). Government-nonprofit relations in times of recession. Kingston: McGill-Queen's University Press.

Levesque, M. (2012). Assessing the ability of disability organizations: An interprovincial comparative perspective. Canadian Journal of Nonprofit and Social Economy Research, 3(2), 82-103.

Levesque, M. (in press-a). Characteristics of disability leaders: An Atlantic Canada profile. Canadian Journal of Disability Studies.

Levesque, M. (in press-b). Learned guidance or guiding the learned? Examining the relationship between disability nonprofit Boards of Directors and their Executive Directors. Journal of Nonprofit and Social Economy Research.

Levine, J. (2016). The privatization of political representation: Community-based organizations as nonelected neighbourhood representatives. American Sociological Review, 81(6), 1251-1275.

Likert, R. (1961). New patterns of management. New York, NY: McGraw-Hill.

Lutz Allen, S., Smith, J., \& da Silva, N. (2013). Leadership style in relation to organizational change and organizational creativity. Nonprofit Management \& Leadership, 24(1), 23-42.

MacGregor Burns, J. (1978). Leadership. New York, NY: Harper Collins.

Mintzberg, H. (2002). Managing care and cure: Up and down, in and out. Health Services Management Research, 15(3), 193-206.

Mitchelmore, S., \& Rowley, J. (2010). Entrepreneurial competencies: A literature review and development agenda. International Journal of Entrepreneurial Behaviour \& Research, 16(2), 92-111.

Mudde, C., \& Rovira Kaltwasser, C. (2017). Populism: A very short introduction. Don Mills: Oxford University Press.

Pearce, C. L., Sims, H. P., Jr., Cox, J. F., Ball, G., Schnell, E., Smith, K. A., \& Trevino, L. (2003). Transactors, transformers and beyond: A multi-method development of a theoretical typology of leadership. The Journal of Management Development, 22(4), 273-307.

Pied, C. (2011). Small town populism and the rise of antigovernment politics. Ethnology, 50(1), 17-41.

Pinchot, G. (1985). Intrapreneuring: Why you don't have to leave the corporation to become an entrepreneur. New York, NY: Harper Collins.

Popa, A. (2012). A quantitative analysis of perceived leadership practices in child welfare organizations. Journal of Public Child Welfare, 6(5), 636-658.

Poza, E. V. (1988). Managerial practices that support interpreneurship and continued growth. Family Business Review, 1(4), 339-359.

Rathgeb Smith, S. (2012). Changing government policy and its implications for nonprofit management education. Nonprofit Management \& Leadership, 23(1), 29-41.

Reiter, R., \& Klenk, T. (2019). The manifold meanings of 'post-new public management': A systematic literature review. International Review of Administrative Sciences, 85(1), 11-27.

Riggio, R., \& Bass, B. (2005). Transformational leadership: A comprehensive review of theory and research (2nd ed.). New York, NY: Psychology Press.

Rodner, V. (2016). Populism in Venezuela: When discourse derails institutionalized practice. Society, 53(6), 629-633. 
Saillant, R. (2014). Over the cliff? Acting now to avoid New Brunswick's bankruptcy. Moncton: Canadian Institute for Research on Public Policy and Public Administration.

Schalock, R. L., \& Verdugo, M. A. (2012). A leadership guide for today's disabilities organizations: Overcoming challenges and making change happen. Baltimore, MD: Paul H. Brookes Publishing.

Scholten, P. (2010). Leadership in policy innovation: A conceptual map. Nature and Culture, 5(1), 31-48.

Senior, P. (2011). The voluntary and community sector: The paradox of becoming centre-stage in the big society. British Journal of Community Justice, 9(1/2), 37-54.

Siegel, D. (2010). The leadership of the municipal chief administrative officer. Canadian Public Administration, 53(2), 139-161.

Statistics Canada. (2014). Canadian survey on disability, 2012 (No. 2014001). Ottawa: Statistics Canada. Retrieved from https://www150.statcan.gc.ca/n1/pub/ 89-654-x/89-654-x2014001-eng.htm

Statistics Canada. (2016). 2016 census of population. Statistics Canada. Retrieved from https://www12. statcan.gc.ca

Stogdill, R. (1948). Personal factors associated with lead- ership: A survey of the literature. Journal of Psychology, 25(1), 35-71.

Stogdill, R., \& Coons, A. (1957). Leader behavior: Its description and measurement. Columbus, $\mathrm{OH}$ : State University Press for Bureau of Business Research.

Szerb, L. (2003). The changing role of entrepreneur and entrepreneurship in network organizations. In I. Lengyel (Ed.), Knowledge transfer, small and mediumsized enterprises, and regional development in Hungary (pp. 81-95). Szeged: JATE Press.

Wang, L., \& Ashcraft, R. (2012). Needs assessment and curriculum mapping: Enhancing management skills of the nonprofit workforce. Nonprofit Management and Leadership, 23(1), 121-136.

Wherry, A. (2018, May 19). Doug Ford is a populist, but it's not clear what kind. CBC News. Retrieved from https://www.cbc.ca/news/politics/doug-fordtrump-populist-analysis-wherry-1.4663465

Wright, B., \& Pandey, S. (2010). Transformational leadership in the public sector: Does structure matter? Journal of Public Administration Research and Theory, 20(1), 75-89.

Yukl, G. (2006). Leadership in organizations (6th ed.). Upper Saddle River, NJ: Prentice Hall.

\section{About the Author}

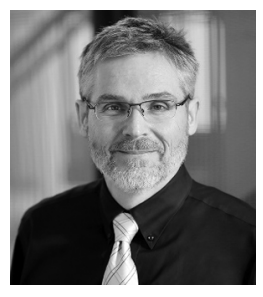

Mario Levesque is an Associate Professor of Canadian Politics and Public Policy in the Department of Politics \& International Relations at Mount Allison University. His teaching and research focus on Canadian politics and public policy analysis related to disability policy (leadership, accessible transportation, political participation, labour market programming) and environmental policy (transboundary resources conflicts). He has published in various journals, including Canadian Public Policy, Canadian Public Administration, Canadian Journal of Disability Studies, Canadian Parliamentary Review, and Journal of Parliamentary and Political Law. 